\title{
A NEW ALGORITHM TO ANALYZE THE VIDEO DATA OF CELL CONTRACTIONS IN MICROFLUIDIC PLATFORMS
}

\author{
N. Nikolov1*, R. Visone², I. Nesteruk1,3, M. Rasponi², A. Redaelly² \\ ${ }^{1}$ ggor Sikorsky Kyiv Polytechnic Institute, Kyiv, Ukraine \\ 2Politecnico di Milano, Milan, Italy \\ IInstitute of Hydromechanics, National Academy of Sciences of Ukraine, Kyiv, Ukraine \\ *Corresponding author: nikolka_@ukr.net \\ Received 11 April 2018; Accepted 11 May 2018
}

\begin{abstract}
Background. One of the rapidly developing trends in science is tissue engineering with use of microfluidic platform (MP) technology. To evaluate mechanical contraction of cells, optical microscopy recordings can be used. Known methods as a matter of fact substantially distort the shape and amplitude of the signal. Therefore, a modified approach is mandatory.

Objective. The development of an algorithm for the analysis of the video data of mechanical oscillations of cardiomyocytes on a microfluidic platform in order to determine their functional and structural properties at the tissue level.

Methods. The developed algorithm for the analysis of video images was implemented by the original program code in Matlab 2016. We analyzed the data of the cardiomyocyte contraction in cells cultured in MPs. Three groups of cells were analyzed: without stimulation and stimulated with electric fields of 5 and $25 \mathrm{~V} / \mathrm{cm}$. The form of the stimulating impulses is rectangular, the frequency is $1 \mathrm{~Hz}$.

Results. An algorithm for the video data analysis is proposed, which allows for estimating the rate of contraction in $\mu \mathrm{m} / \mathrm{s}$. Moreover, it allows for decomposing the mechanical oscillations of cells into components. The algorithm has been used to evaluate the change in the contraction rate of cardiomyocytes cultured in a lab-on-chip, as a function of voltage intensity and excitation frequency under different experimental conditions.

Conclusions. The proposed method does not require any auxiliary biomarkers or media. Analysis of video images allows us to estimate the amplitude and rate of oscillations, the shape of the signal, the spatial heterogeneity distribution of the mechanical activity of cells. Our results show that the pulsed electric field in the range $5-25 \mathrm{~V} / \mathrm{cm}$ at frequencies of $1 \mathrm{~Hz}$ during cell cultivation affects negatively the mechanical functional abilities of cardiomyocytes.
\end{abstract}

Keywords: cardiomyocyte; cell; organ-on-chip; oscillations; algorithm; video data; optical microscopy; tissue engineering.

\section{Introduction}

One of the rapidly developing trends in science is tissue engineering. Its goal is the creation of biological tissue with prescribed properties. One possible approach consists in culturing cells in microfluidic platforms (MPs) [1-4]. Such technologies allow for studying a proto-tissue or organ at the miscroscale resembling the principal features of the organ of. In general, MP can be successfully used to:

- improve the technology of tissue cultivation;

- determine the optimal conditions for creating tissues with given properties;

- study the biophysical properties of interrelated groups of cells;

- model pathological processes at the tissue level;
- study the effect of external physical factors and therapeutic drugs on tissue;

- develop and optimize clinical diagnostic tests by determining the individual susceptibility of the patient's tissues to physical factors and therapeutic drugs.

Various chemical biomarkers and mediums have been widely used to study the morphological and functional properties of tissues. For example, in $[5,6]$ medias and preparations for determining the proliferate activity of cells and phases of the cell's life cycle, the number of dead and living cells, wave processes of spread of the front to stimulation with use and action potentials are given. The fundamental importance of using biomarkers is their specificity. However, we can identify a number of shortcomings of this approach. In most cases, biomarkers are quite expensive; their use requires special knowledge, skills, and appropriate equipment. 
When culturing cardiomyocytes on an MP, the most important functional test consists in the evaluation of their contractility. One of the methods for evaluating mechanical contractions of cells is optical microscopy [7, 2]. The method does not require the use of additional biochemical preparations and the use of confocal microscopy. Cell contraction are evaluated on the basis of video data, which are obtained with conventional light microscopes. The technique allows for visualizing both spontaneous beats and evaluating cell oscillations under the influence of an external electric field, e.g., "pseudoECG" [2]. To obtain quantitative characteristics of mechanical cell contractions without the use of auxiliary reagents, the task of computer processing and analysis of video images is posed.

In similar studies $[2,8,9,10]$, where the amplitude of cardiomyocyte oscillations is estimated from the analysis of video images, the average change in brightness in the region of interest is measured. The size of this region usually is substantially smaller than the "useful area" of the microchip with cells and the method of estimating the oscillations is simple enough but has two significant drawbacks. First, the amplitude units of measurement is not calibrated, i.e., they are measured by levels of brightness. It means that it is impossible to estimate correctly cell oscillations in different areas of the microchip since the images are not always ideally illuminated by a uniform external light source, but also because of the variation in cell density in space. Analyzing the signal by luminance gradations (gray levels) when comparing the data of different experiments would require careful calibration. Another disadvantage is the distortion of the waveform characterizing the mechanical contraction of cells. This leads to a change in the balance of brightness (similar to the balance of mass or energy in physical tasks). In addition, the brightness of the optical image changes not only because of cells mechanical oscillations but also due to the polarization of the cell elements under the action of the external field. The overall brightness of the optical image of the cells varies nonlinearly with the change in the strength of the external field and the frequency of the effect. Thus, the known methods, for example, $[2,8,9,10]$, register the very fact of cell contraction but substantially distort the shape and amplitude of the useful signal.

The aim of this study is the development of an algorithm for the analysis of the video data of mechanical contraction of cardiomyocytes on an MP to determine their functional and structural properties at the tissue level.

\section{Materials and Methods}

The developed algorithm for the analysis of video images was implemented in Matlab 2016. We analyzed the data of the contraction of cardiomyocytes cultured in an MP. The video data of cardiomyocyte contraction was recorded in the file format "mp4", where the color information in a pixel was recorded in the "RGB24" format. The recording rate was 23.83 frame/s. Subsequently, the images were transferred from the RGB format to grayscale images.

The geometric and functional features of the microchip described in [8]. Cells are embedded in fibrin hydrogel and then injected into the microchips, cultured in DMEM high glucose [11] and stimulated according to the following 3 conditions:

- Condition A: without any stimulation for 5 days.

- Condition B: without any stimulation for 3 days and subsequently electrically stimulated for the resting 2 days (day 4 and day 5). The electric pulse is $0,6 \mathrm{~V}$ amplitude (electric field $5 \mathrm{~V} / \mathrm{cm}$, current density $\left.14.8 \mathrm{~mA} / \mathrm{cm}^{2}\right), 2 \mathrm{~ms}$ positive, $2 \mathrm{~ms}$ negative and $0 \mathrm{~V}$ for the resting $996 \mathrm{~ms}$; frequency $-1 \mathrm{~Hz}$.

- Condition C: without any stimulation for 3 days and subsequently stimulated for the resting 2 days (day 4 and day 5). The electric pulse is $3 \mathrm{~V}$ amplitude (electric field $25 \mathrm{~V} / \mathrm{cm}$, current density $\left.74 \mathrm{~mA} / \mathrm{cm}^{2}\right), 2 \mathrm{~ms}$ positive, $2 \mathrm{~ms}$ negative and $0 \mathrm{~V}$ for the resting $996 \mathrm{~ms}$; frequency $1 \mathrm{~Hz}$.

Video image were obtained after 5 days of culture. To stimulate the contraction, the chips were stimulated by a unipolar rectangular signal with a duty ratio of 2 . The amplitude of the pulses was varied in the range $0-7 \mathrm{~V}$, the frequency was $0-5.5 \mathrm{~Hz}$

The algorithm for the analysis of cardiomyocyte contraction on an MP consists of the following sequence of actions:

1. Video data are loaded.

2. Images (definition of the geometrical sizes of pixels) are calibrated.

3. A rectangular region of interest is defined.

4. Binary images of local maxima in each frame of the video sequence are created.

5. Binary images of local maxima and binarization of the resulting image at the $\alpha$-level of 0.5 is performed.

6. In the neighborhood of the obtained points in the spatial window of 9 pixels on each frame, the radius $(R)$ and angle $(\theta)$ formed by the vector between the center of mass of the pixel brightness are calculated. 
7. The changing rate of $R$ and $\theta$ in time are calculated : $\Delta R / \Delta t$ and $\Delta \theta / \Delta t$.

8. The Region of Interest (ROI) along $X$ and $Y$ axis are stratified.

9. The calculated data $R$ and $\theta, \Delta R / \Delta t$ and $\Delta \theta / \Delta t$ in the strata for each time frame of the video sequence are averaged in space.

10. The obtained data, i.e., the shape of the oscillations in time, spectral Fourier analysis, correlation of oscillations between strata are analyzed.

The determination of the geometric dimensions of the pixels was carried out with respect to the $300 \mu \mathrm{m}$ distance between the geometric centers of the columns shown in Fig. 1. In our case one pixel was equal $1.43 \mu \mathrm{m}$.

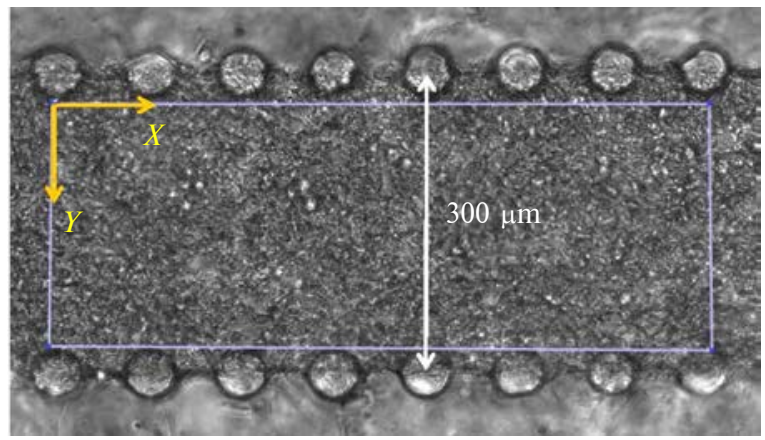

Figure 1: Building an ROI and calibrating the geometric size of pixels

After ROI building, local maxima $\left(\mathrm{BW}_{\max }(t)\right)$ are searched for each video frame. It is assumed that these points determine the coordinates of cardiomyocytes, since the elements of the cytoskeleton have the largest optical density, which is visualized as the brightest (almost white) areas on the images. It should be kept in mind that during contraction cells change their geometric dimensions and move for a certain distance in space. In addition, a noise exists in the images. Therefore, to find the average equilibrium coordinate of the cells, all values of $\mathrm{BW}_{\max }(t)$ were summed up:

$$
B_{\Sigma}=\sum_{i=1}^{n_{t}} \mathrm{BW}(i)
$$

where $n_{t}$ is a number of frames.

The resulting $B_{\Sigma}$ image was normalized to the maximum value and binarized at $0.5\left(\mathrm{~B}_{\Sigma 0.5}\right)$. The obtained points with the value of 1 were identified with the geometric centers of the cells. This technique allows avoiding the use of the alignment procedure for the non-uniform illuminating images and significantly reduces the computer time for analyzing the video stream, i.e., there is no need to process every pixel of images. We note that each cell may have several non-zero pixels $B_{\Sigma 0.5}$. However, it should be emphasized that for the video images with a higher degree of spatial resolution, the thresholding technique may be different, for example, a relatively narrow range of brightness can be used.

The oscillation analysis of an individual cardiomyocyte was performed in the neighborhood of nonzero pixels $B_{\Sigma 0.5}$, which we conditionally call "active image points" (AIP). The neighborhood of the AIP was defined by a rectangular area of \pm 4 pixels, that is, the window size was 9 pixels $(6.3 \mu \mathrm{m})$. The size of the window was determined by two factors. First, given the resolution of video images, the distance between non-zero pixels $B_{\Sigma 0.5}$ was $5-20$ pixels. The second factor was the requirement that if the window size in the microchip area was increased, where the cells were a priori absent, the measured signal (for example, the average brightness) would change minimally. The maximum window size should not exceed the maximum cell size of cardiomyocytes, which is about $24 \mu \mathrm{m}$. The relative error of the amplitudes of the oscillations (variable component) between the data obtained with the windows 9, 11, 13,15 did not exceed $5-10 \%$ in our studies. In this regard, to minimize the machine resources, a window of 9 pixels was selected (see Fig. 2).

For the analysis of cell contraction, two main parameters were chosen: the radius and the angle formed by the vector between the geometric center of the window (the neighborhood of the non-zero point in image $\mathrm{B}_{\Sigma 0.5}$ ) and the center of mass of the brightness of the window (Fig. 3).

When stimulating the cell oscillations with an external electrical signal, the electric field lines are directed along the $X$ or $Y$ axis. The spatial orientation of cardiomyocytes with respect to field lines can be considered as random one. In connection with this, it is also rational to estimate the components of the radius of oscillations $R_{x}$ and $R_{y}$ :

$$
R=\sqrt{R_{x}^{2}+R_{y}^{2}} .
$$

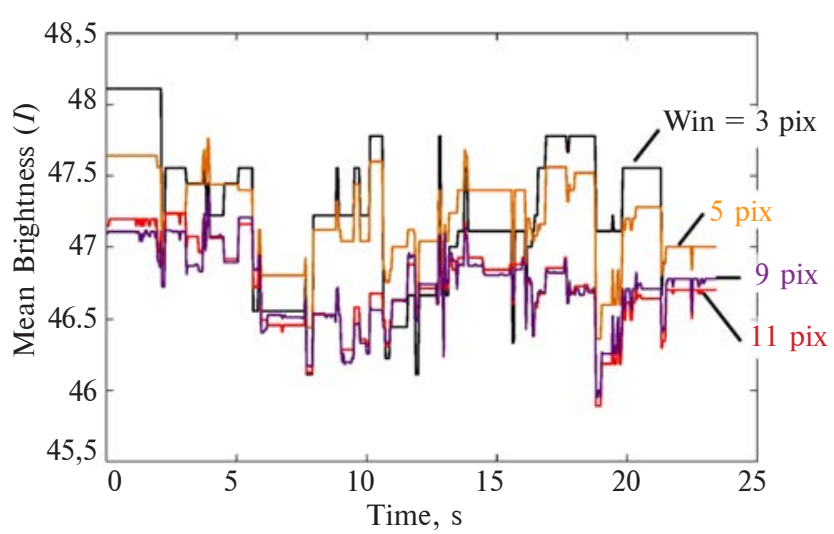

Figure 2: Selection of the window size. In the area without cells, increasing the window size should not change the value of the average brightness 


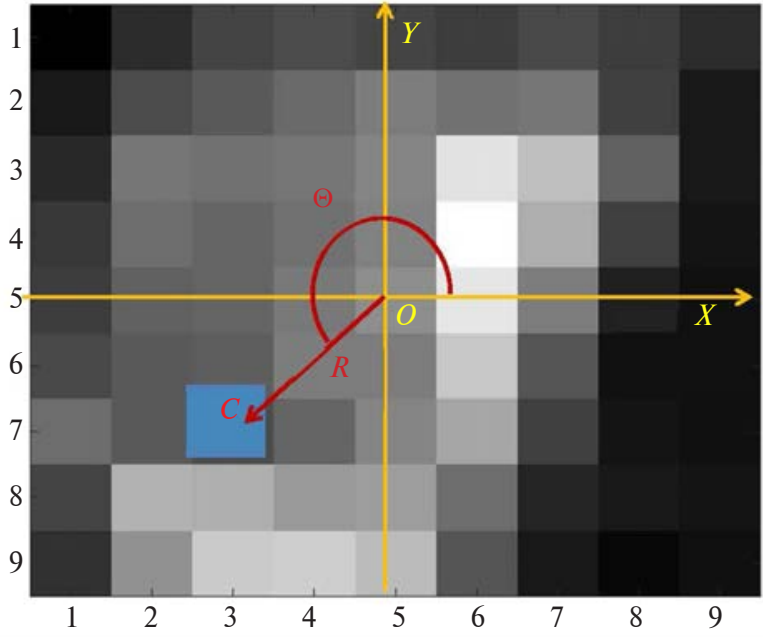

Figure 3: Determination of the radius $(R)$ and angle $(\Theta)$ : $O[$ is the geometric center; $C$ is the center of mass of brightness. Unit of $x$ and $y$ is pixel as follows:

The time derivatives $\Delta_{t} R, \Delta_{t} \Theta$ were estimated

$$
\begin{gathered}
\Delta_{t} R \equiv \Delta R / \Delta t \approx\left[R\left(n_{t}+1\right)-R\left(n_{t}\right)\right] / \Delta t, \\
\Delta_{t} \Theta \equiv \Delta \Theta / \Delta t \approx\left[\Theta\left(n_{t}+1\right)-\Theta\left(n_{t}\right)\right] / \Delta t
\end{gathered}
$$

where $\Delta t$ was $1 / 23.83 \mathrm{~s} ; n_{t}$ is a frame number of the video sequence (time).

Thus, the vector $\mathbf{D}=\left(i, X_{i}, Y_{i}, n_{t}, R_{i}, \Theta_{i}, R_{x i}\right.$, $\left.R_{y i}, \Delta_{t} R_{i}, \Delta_{t} \Theta_{i}\right)$ is formed, where $i$ is a sequence number of the AIP, $X_{i}$ and $Y_{i}$ are the coordinates of the $i$-th point.

To average the data, the ROI space was divided into strata (subranges) along the $X$ and $Y$ axis. The number of striations along the given axis $N_{\text {str } X}$ or $N_{\text {str } Y}$ was determined by the H.A. Sturges formula

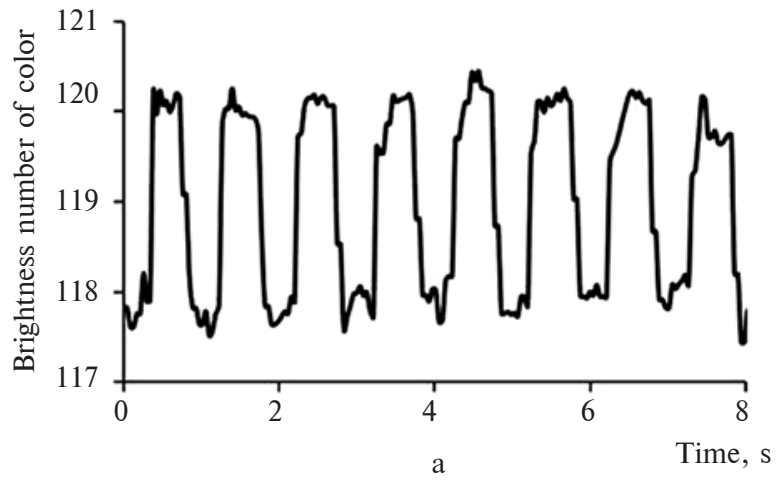

$$
\begin{aligned}
& N_{\text {str } X}=1+\left|\log _{2} N_{X}\right|, \\
& N_{\text {str } Y}=1+\left|\log _{2} N_{Y}\right|
\end{aligned}
$$

where $N_{X}$ and $N_{Y}$ are the number of pixels in the ROI along the $X$ and $Y$ axes, respectively. The vectors $\mathbf{D}_{i}$, which coordinates $X_{i}, Y_{i}$ correspond to the given stratum, are averaged.

According to the time variation of $R_{i}, \Theta_{i}$ it is possible to evaluate the contraction mode of the cells, and also distinguish low-amplitude oscillations from noise random components.

The subsequent analysis of the signals consisted of a correlation analysis of the oscillations of the mean values of $R, R_{x}, R_{y}, \Theta, \Delta_{t} R, \Delta_{\mathrm{t}} \Theta$ between strata, and also in the analysis of Fourier spectra. In the striations along the $X$ axis, the components of the contraction $R_{y}$ were analyzed, and, conversely, in the strata along the $Y$ axis, the average oscillations of $R_{x}$ were estimated.

The image processing method described above substantially reduces these drawbacks. In addition, the method makes it possible to estimate the magnitude of cell contraction in absolute units of $\mu \mathrm{m}$, and the rate of oscillations is $\mu \mathrm{m} / \mathrm{s}$, and to decompose the mechanical oscillations of cells into components.

Shape of the pulses of mechanical oscillations of cardiomyocytes during their electrical stimulation are presented in Fig. 4. It can be seen that the form of the oscillations of the average brightness tends to rectangular. The oscillations of the radius $\mathrm{R}$ have a more complex form. Such a form of signal (Fig. 4b) is similar to the data in [6].

Among all AIP a sufficiently large number of points not belonging to the cells is present. This is largely due to the fact that the environment and micro-inclusions, including inactive and dead cells, also perform mechanical contractions.

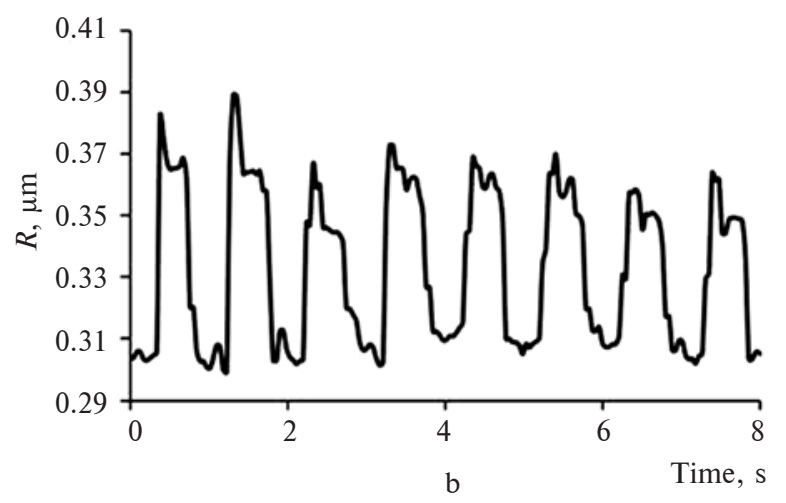

Figure 4: The shape of the pulses of mechanical cell contractions at the stimulation frequency of $1 \mathrm{~Hz}$ and voltage $4.5 \mathrm{~V}$, estimated by different methods: (a) according to the average brightness in the zone of interest; (b) the value of the radius of the deviation of the center of mass of brightness from the geometric center (see text) 
These points can significantly affect the results of averaging the data. It is possible to distinguish the AIPs belonging to living cells from the others when comparing the shape of the pulses of mechanical oscillations: AIP non-belonging cells are characterized by low-amplitude almost chaotic oscillations. However, comparing the forms of oscillatory processes between all AIP requires a lot of computer resources. Alternatively, the following method is proposed. For each AIP the obtained values of $\Delta_{t} R_{\max }$ we normalize with respect to their maximal value $\max \left(\Delta_{t} R_{\max i}\right)$, where $i=1, \ldots, n$ ( $n$ is the total number of AIPs). Those points for which the normalized values $\Delta_{t} R_{\max }$ are less than a certain threshold level $\beta$ are excluded from the analysis. In Fig. 5 an example of an estimation of the change in the shape of mechanical oscillations of cells is shown as a function of the level $\beta(0<\beta<1)$.

The data in Fig. 5 show that the amplitude of the oscillations increases with increasing $\beta$ (to 0.5 ); the shape of the pulse for $\beta>0$ is quite different from the data for $\beta=0$ (when all AIP are taken into account). The use of $\beta>0.5$ is not rational, since in these cases the amount of AIP sharply decreases (Fig. 6), and the average data become sensitive to single relatively high-amplitude fluctuations.

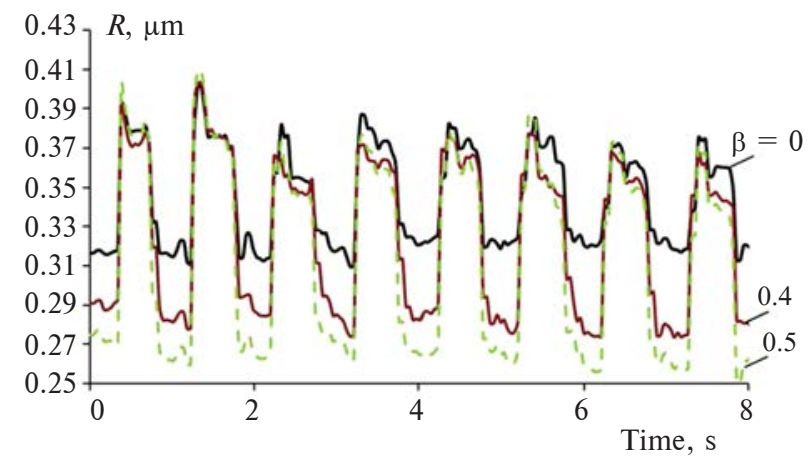

Figure 5: The shape of the pulses of mechanical cell contractions when stimulating oscillations of $1 \mathrm{~Hz}$ and $4.5 \mathrm{~V}$ are applied, estimated for different values of $\beta$

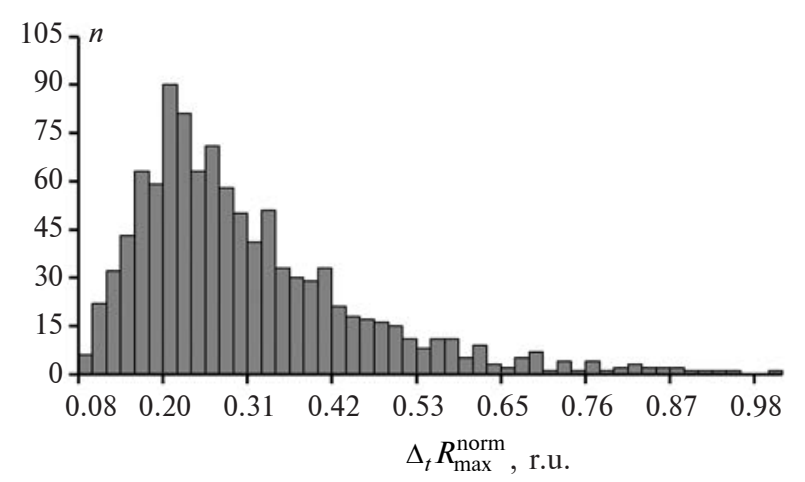

Figure 6: The histogram of the distribution of the normalized maximum values $\Delta_{t} R_{\max }$. With $\beta=\Delta_{t} R_{\max }^{\text {norm }}>0.5$ the amount of AIP decreases significantly

\section{Results}

To approximate the average data, the equation

$$
\Delta_{t} R_{\max }=a f^{\lambda}
$$

was chosen, where $f$ is the stimulation frequency, $a$ and $\lambda$ are parameters.

An example of the approximation of the average values of oscillations as a function of the stimulation frequency under different voltage on electrodes is presented in Fig. 7.

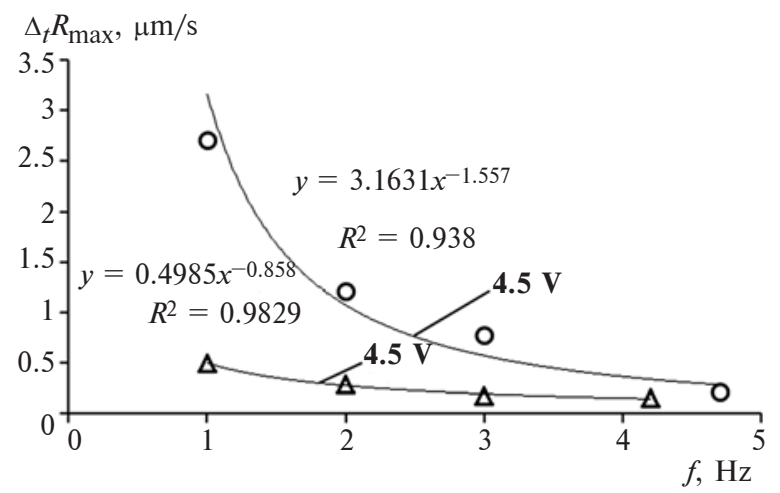

Figure 7: Change in the rate of contraction of cardiomyocytes in the microchip, depending on the voltage and excitation frequency for the control group (A). $R^{2}$ is the square of the correlation coefficient between the approximation function and the experimental data

The quantitative values of the approximation of the experimental data are presented in the Table, where $R^{2}$ is a square of the correlation coefficient between the approximation function and experimental data.

According to the Table, the following conclusions can be drowned out: with the increase of the stimulating frequency, the amplitude of mechanical contractions decreases monotonically; for cells stimulated with electrical stimuli (groups B and C), the parameters $a$ and $\lambda$ decrease (in comparison with the group A), which indicates a decrease in the excitability of cells and the ability to perform mechanical work. A similar conclusion can be drown out by comparing groups $\mathrm{B}$ and $\mathrm{C}$ : an increase in the strength of the external electric field during the cell culture entails a decrease in the functional capability of cells. In group $\mathrm{C}$, at the stimulation voltage of $4.95 \mathrm{~V}$, there is a certain deviation from the presented general conclusions: the parameter $a$ exceeds the corresponding value at the voltage of $4.5 \mathrm{~V}$. This observation can be explained by the fact that the measurements were carried out on different microchips and every biological system has its own individual characteristics. 
Table: The approximation functions for the maximum rate of cell contraction $(\mu \mathrm{m} / \mathrm{s})$ cultivated under different conditions, depending on the frequency and the stimulation voltage of the oscillations

\begin{tabular}{|c|c|c|c|}
\hline Group of microchips & Paran & $\lambda$ and $\lambda$ of approximatic & tions \\
\hline \multirow{2}{*}{ A } & $\begin{array}{c}4.5 \mathrm{~V} \\
f \in[1 . .4 .7] \mathrm{Hz}\end{array}$ & $\begin{array}{c}4.8 \mathrm{~V}, \\
f \in[1 . .4 .2] \mathrm{Hz}\end{array}$ & $\begin{aligned} & 5.25 \mathrm{~V} \\
& f \in[1 . .4 .6] \mathrm{Hz}\end{aligned}$ \\
\hline & $\begin{aligned} a= & 3.16, \lambda=-1.557 \\
& \left(R^{2}=0.95\right)\end{aligned}$ & $\begin{aligned} a= & 0.50, \lambda=-0.858 \\
& \left(R^{2}=0.71\right)\end{aligned}$ & $\begin{aligned} a= & 0.20, \lambda=-0.786 \\
& \left(R^{2}=0.38\right)\end{aligned}$ \\
\hline \multirow{2}{*}{ B } & $\begin{array}{c}3.75 \mathrm{~V} \\
f \in[1 . .5] \mathrm{Hz}\end{array}$ & $\begin{array}{c}6.6 \mathrm{~V}, \\
f \in[1 . .5 .5] \mathrm{Hz}\end{array}$ & - \\
\hline & $\begin{aligned} a= & 0,99, \lambda=-0.908 \\
& \left(R^{2}=0.72\right)\end{aligned}$ & $\begin{aligned} a= & 0.15, \lambda=-0.561 \\
& \left(R^{2}=0.48\right)\end{aligned}$ & - \\
\hline \multirow{2}{*}{$\mathrm{C}$} & $\begin{array}{c}3.9 \mathrm{~V} \\
f \in[1 . .4 .8] \mathrm{Hz}\end{array}$ & $\begin{array}{c}4.5 \mathrm{~V} \\
f \in[1 . .3] \mathrm{Hz}\end{array}$ & $\begin{aligned} & 4.95 \mathrm{~V} \\
& f \in[1 . .5 .2] \mathrm{Hz}\end{aligned}$ \\
\hline & $\begin{aligned} a= & 0.62, \lambda=-0.706 \\
& \left(R^{2}=0.97\right)\end{aligned}$ & $\begin{aligned} a= & 0.20, \lambda=-0.898 \\
& \left(R^{2}=0.49\right)\end{aligned}$ & $\begin{aligned} a= & 0.27, \lambda=-0.765 \\
& \left(R^{2}=0.92\right)\end{aligned}$ \\
\hline
\end{tabular}

The presented analysis technique allows estimating the wave processes of spread contractions as well (see Fig. 8).

The wave character (when present) is clearly noticeable on two-dimensional time histograms $\Delta_{t} R$ along the $X$ and $Y$ axes, see Fig. 9a. It can be seen that the component of the rate of cell contraction $\Delta_{t} R_{Y}$ lags behind the right edge of the microchip compared to the origin (the left edge of the microchip). At the same time, cell contractions in strata along the $\mathrm{Y}$ axis occur simultaneously (Fig. 9b).

Active cardiomyocytes on a microchip are distributed non-uniform in space. Therefore, the shape of the impulses can be different in different strata. When the stimulation conditions change, the most active regions can shift. The Fig. 10 shows examples of different pulse shape changes

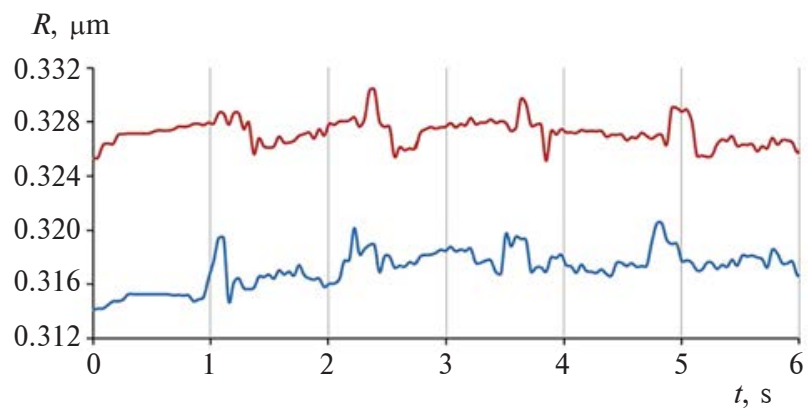

Figure 8: Example of a wave process in a microchip (Condition B, stimulation $1 \mathrm{~Hz} 4 \mathrm{~V}$ ). The wave propagates along the $\mathrm{X}$ axis, which leads to a delay in cell contraction in the strata. The distance between strata is $380 \mu \mathrm{m}$, the width of strata is $54 \mu \mathrm{m}$. The blue curve is the oscillations in left strata, the red curve is the oscillations in the right strata
$R_{x}$ and $R_{y}$ in one of the chips. The oscillations along $R_{x}$ and $R_{y}$ axis maybe depended on the way cells remodeled the matrix and re-organized themselves.

At the stimulation frequency of $1 \mathrm{~Hz}$ the maximum amplitude of oscillations was observed (see Fig. 10a). The change in the constant component is also noted. The shape of the pulses changes, when the frequency increases. This phenomenon is observed at frequencies higher than $2 \mathrm{~Hz}$. Figure $10 \mathrm{~b}$ demonstrates that sometimes there are oscillations with opposite phase of contraction. Probably the phase shift between $R_{x}$ and $R_{y}$ depends on the number of cellular contacts between the cells and their orientation in space. Oscillations are antiphase if there are few contacts and the cells do not depend on neighbors. The absence of a pronounced phase shift indicates that the cells are oriented with respect to the external field randomly and the direction of the oscillations depends on the neighbors. Nevertheless, it can be stated that along the direction of the lines of external field force the amplitude of the oscillation is usually more pronounced (red curves).

In addition, in most cases asymmetry of the amplitude of cell contraction near two different stimulating electrodes is observed. For example, Fig. 9b shows that the speed and the amplitude of oscillations are higher in the upper part than in the lower one. This is due to the redistribution of charges in the medium. From the methods of electro-physiotherapy (galvanization, electrophoresis, low-frequency methods of exposure) it is known that under the anode a more acidic environment is formed and the sensitivity of tissues decreases, 


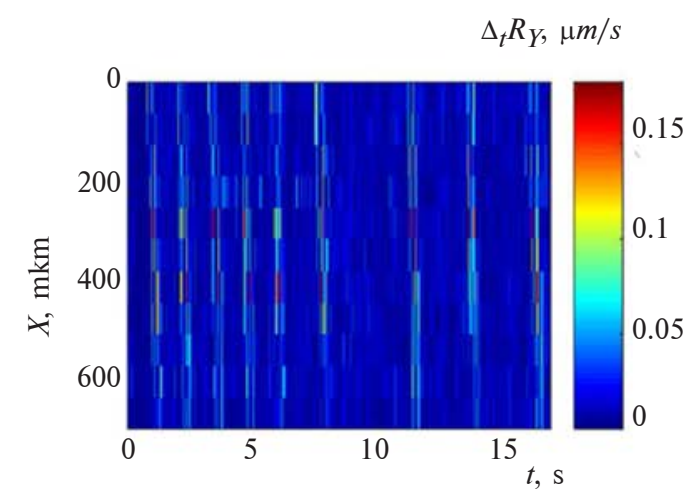

a

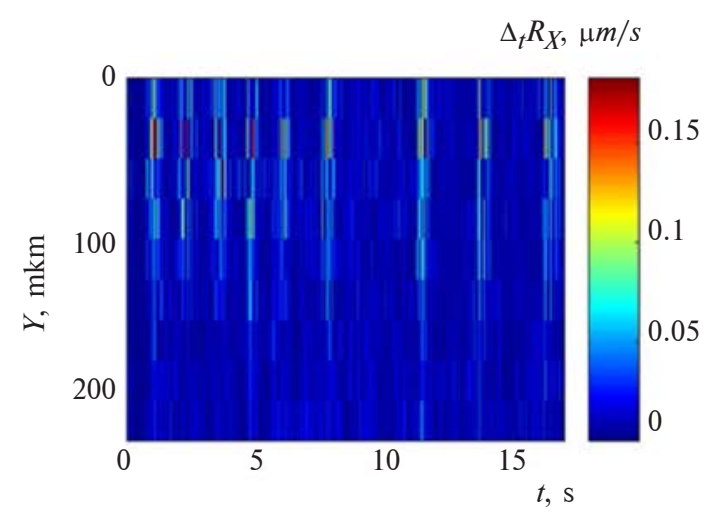

b

Figure 9: The spread of the average rate of cell contraction in the strata along the axis versus time: (a) along $X$ axis (bright strips that correspond to the maximum rate of the beat are inclined); (b) along $Y$ axis

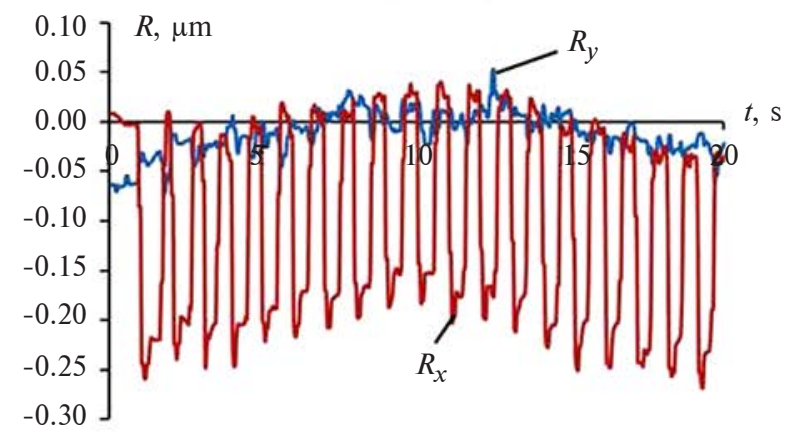

a

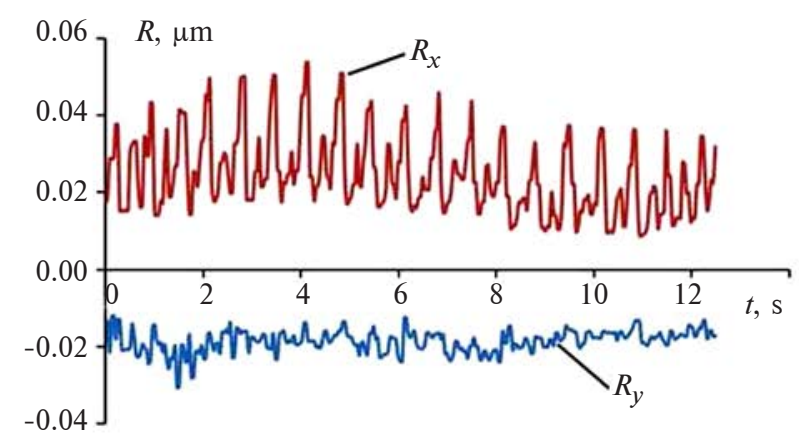

$\mathrm{c}$

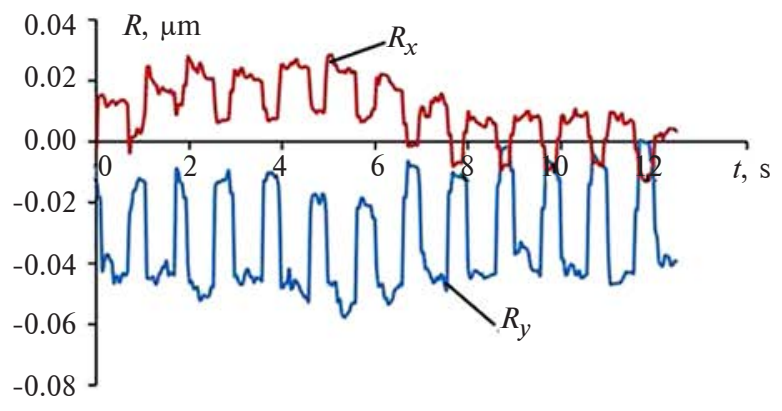

b

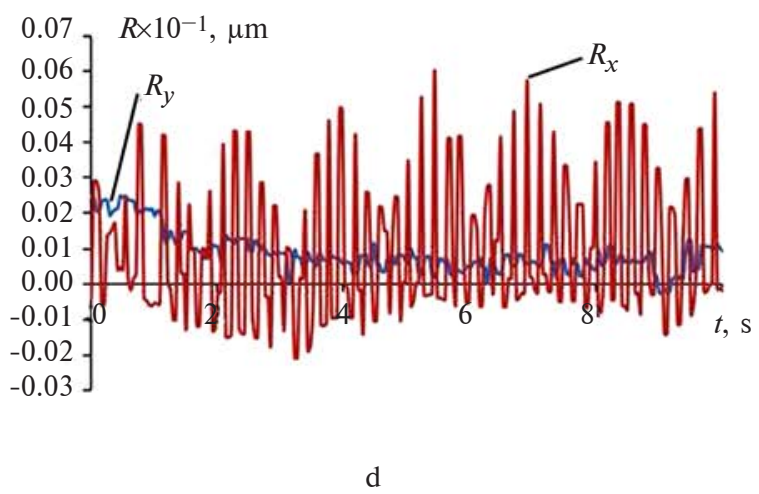

Figure 10: Examples of changes in the shape of the pulses of cell oscillations at different frequencies: (a) $1 \mathrm{~Hz}$, (b) $1 \mathrm{~Hz}$, (c) $3 \mathrm{~Hz}$, (d) $4 \mathrm{~Hz}$

under the cathode there is an increase in $\mathrm{pH}$ and an increase in the sensitivity of tissues [12]. In turn, this indicates that when testing the electromechanical properties of cells in a microchip as a complete system, it is necessary or to increase the duty cycle of the exciting external pulses and/or use to a bipolar signal. This will make it possible to restore the spatial distribution of ions. Since the mobility of positive and negative ions is different, one should also limit the time of one measurement and make substantially larger pauses between measurements on a single chip. With an increase in the oscillation frequency of more than $2 \mathrm{~Hz}$, a low-frequency modulation of the pulse shape is often observed (see Fig. 10d).

It should be noted that at this stage of the study the analysis of the time variation of the parameters $\Theta, \Delta_{t} \Theta$ did not provide additional useful information. These parameters correlated well with the amplitude characteristics but had a slightly larger 
noise component. However $\Theta$ and $\Delta_{t} \Theta$ can be of interest for cluster space-time analysis.

The spatial heterogeneity in the mechanical activity of cells can also be considered with the use of maps of the oscillation rate distribution (Fig. 11). The size of one pixel on these maps corresponds to the size of the strata along the corresponding axis. As a rule, with increasing the stimulation frequency, the spatial distribution of active cells is generally preserved. Blurring and coarse patterns of activity are observed. Fig. 11 illustrates that at the frequency of $5 \mathrm{~Hz}$, the amplitude of the oscillations is sharply reduced, but the activity region is the largest.
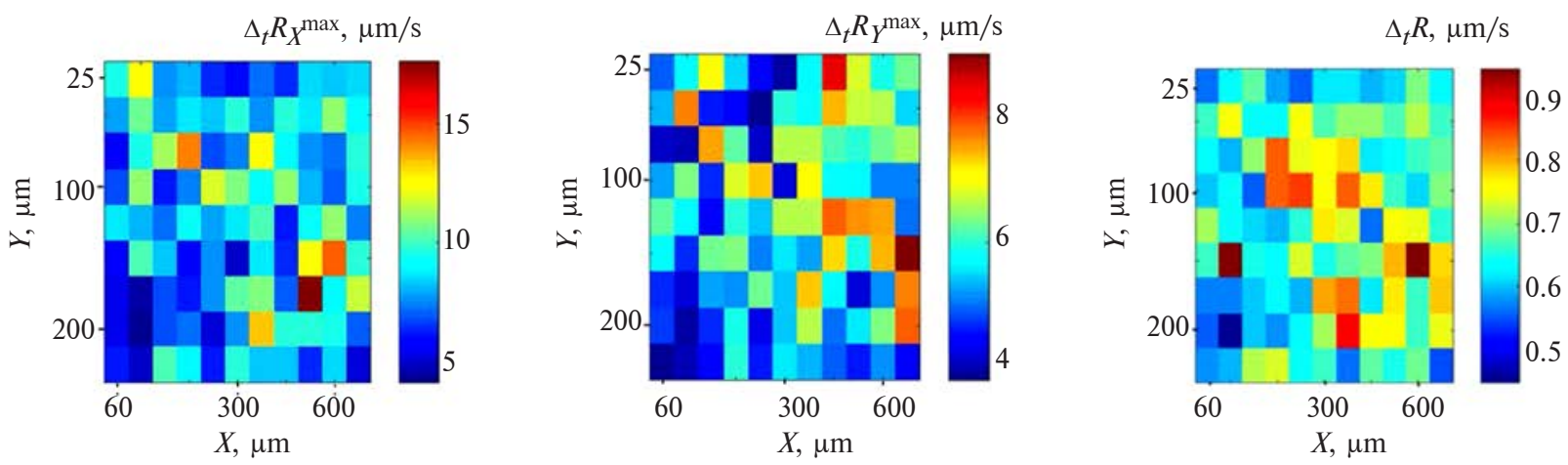

a
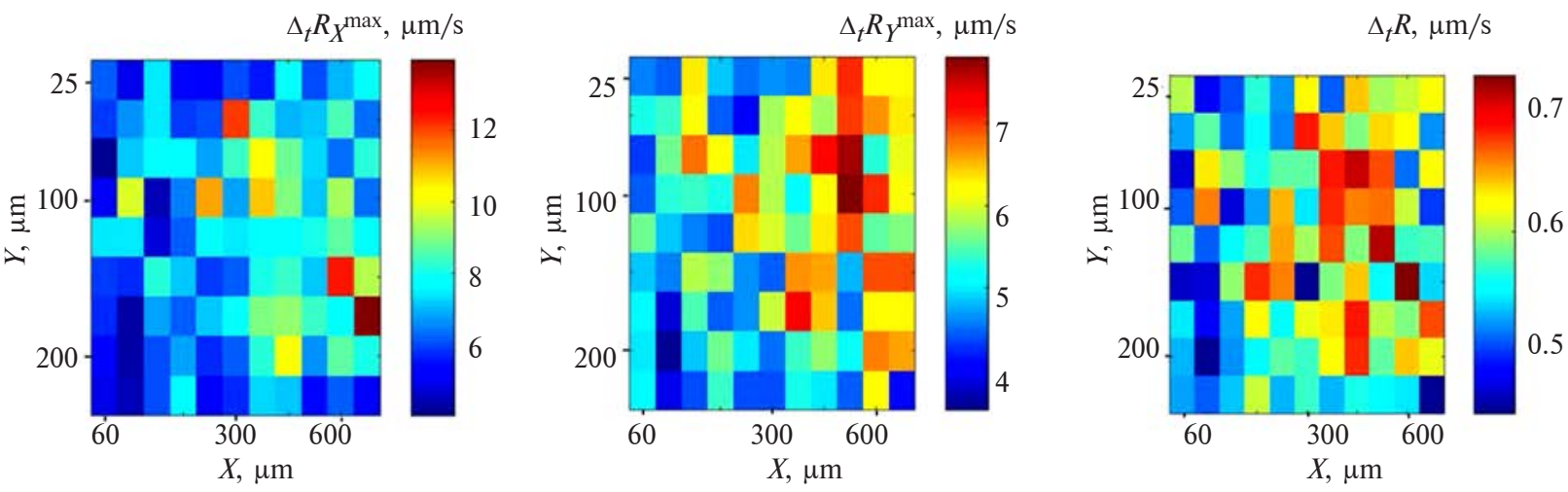

b
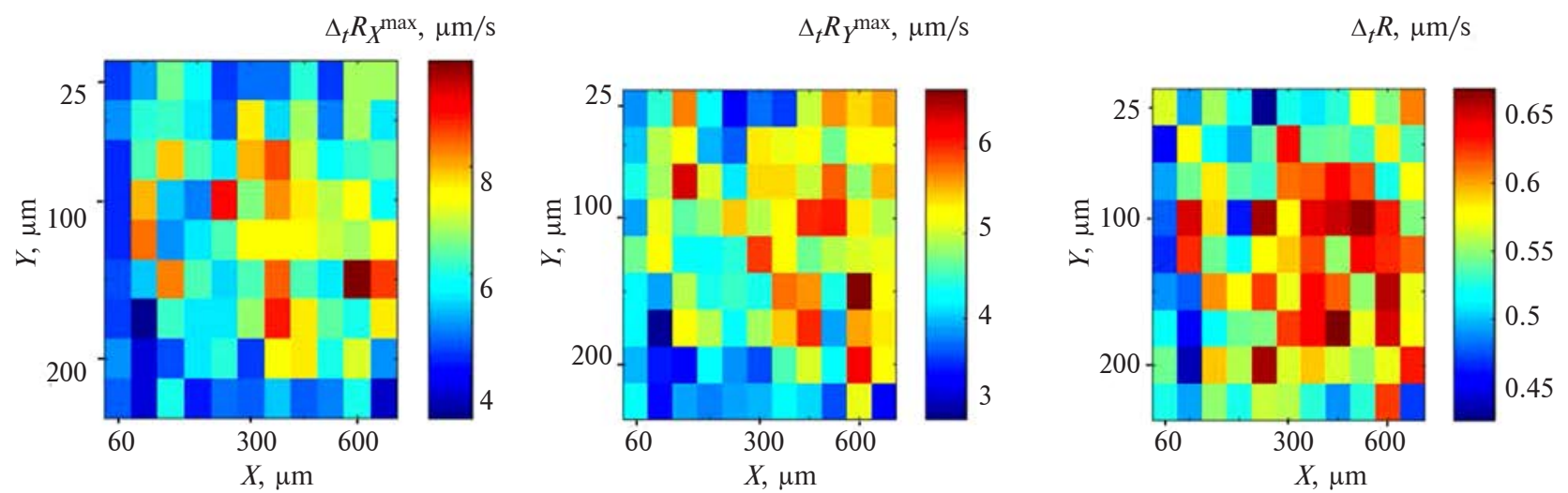

Figure 11: Example of the change in the spatial heterogeneity of the mechanical activity of cells as a function of the stimulation frequency (the voltage is constant $-3.75 \mathrm{~V}$ ) for Condition B: (a) $1 \mathrm{~Hz}$, (b) $3 \mathrm{~Hz}$, (c) $5 \mathrm{~Hz}$. $\Delta_{t} R_{X} \max , \Delta_{t} R_{Y} \max$ are the average value of the maximum oscillation rate along the axes $X$ and $Y$ 


\section{Conclusions}

An algorithm for analyzing the oscillations of cardiomyocytes on an MP was developed based on optical microscopy video data. The technique does not require any auxiliary biomarkers or media. Analysis of video images allows us to estimate the amplitude and rate of contractions, the shape of the signal, the spatial heterogeneity distribution of the mechanical activity of cells.

The developed algorithm was used for the analysis of cell contraction under different culture conditions. It was shown that the pulsed electric field in the range $5-25 \mathrm{~V} / \mathrm{cm}$ at frequencies of $1 \mathrm{~Hz}$ during cell culture affects negatively the mechanical functional abilities of cardiomyocyte cells.

Further improvement of the proposed method of analysis is associated with a decrease computer time of the analysis of the video data and the determination of specific properties of cardiomyocytes at the tissue level.

\section{Funding}

The study was supported by EU-financed Horizon-2020 project AMMODIT (Grant Number MSCA-RISE 645672).

\section{References}

[1] Rohr S, Scholly DM, Kleber AG. Patterned growth of neonatal rat heart cells in culture morphological and electrophysiological characterization. Circulation Res. 1991;68:114-30. DOI: 10.1161/01.RES.68.1.114

[2] Teplenin A, Krasheninnikova A, Agladze N, Sidoruk K, Agapova O, Agapov I, et al. Functional analysis of the engineered cardiac tissue grown on recombinant spidroin fiber meshes. PLoS ONE. 2015;10(3):e0121155. DOI: 10.1371/journal.pone.0121155

[3] Wang X, Chen S, Kong M, Wang Z, Costa KD, Li RA, et al. Enhanced cell sorting and manipulation with combined optical tweezer and microfluidic chip technologies. Lab Chip. 2011;11:3656-62. DOI: 10.1039/C1LC20653B

[4] Wikswo JP, Curtis EL, Eagleton ZE, Evans BC, Kole A, Hofmeisterab LH, et al. Scaling and systems biology for integrating multiple organs-on-a-chip. Lab Chip. 2013;13:3496-511. DOI: 10.1039/C3LC50243K

[5] Burridge P, Thompson S, Millrod M, Weinberg S, Yuan X, Peters A, et al. A universal system for highly efficient cardiac differentiation of human induced pluripotent stem cells that eliminates interline variability. PLoS ONE. 2011;6(4):e18293. DOI: 10.1371/journal.pone.0018293

[6] Huebsch N, Loskill P, Mandegar MA, Marks NC, Sheehan AS, Ma Z, et al. Automated video-based analysis of contractility and calcium flux in human-induced pluripotent stem cell-derived cardiomyocytes cultured over different spatial scales. Tissue Eng Part C. 2015;21(5):467-79. DOI: 10.1089/ten.TEC.2014.0283

[7] Maddah M, Heidmann J, Mandegar M, Walker C, Bolouki S, Conklin B, et al. A non-invasive platform for functional characterization of stem-cell-derived cardiomyocytes with applications in cardiotoxicity testing. Stem Cell Reports. 2015;4(4):62131. DOI: $10.1016 /$ j.stemcr.2015.02.007

[8] Marsano A, Conficconi C, Lemme M, Occhetta P, Gaudiello E, Votta E, et al. Beating heart on a chip: A novel microfluidic platform to generate functional 3D cardiac microtissues. LabChip. 2016 Feb 7;16(3):599-610. DOI: 10.1039/C5LC01356A

[9] Werley CA, Chien MP, Gaublomme J, Shekhar K, Butty V, Yi BA, et al. Geometry-dependent functional changes in iPSCderived cardiomyocytes probed by functional imaging and RNA sequencing. PLoS ONE. 2017;12(3):e0172671. DOI: 10.1371/ journal.pone. 0172671

[10] Burridge PW, Thompson S, Millrod MA, Weinberg S, Yuan X, Peters A, et al. A universal system for highly efficient cardiac differentiation of human induced pluripotent stem cells that eliminates interline variability. PLoS ONE. 2011;6(4):e18293. DOI: 10.1371/journal.pone.0018293

[11] 41965 - DMEM, high glucose | Thermo Fisher Scientific [Internet]. Thermofisher.com. 2018 [cited 10 April 2018]. Available from: https://www.thermofisher.com/it/en/home/technical-resources/media-formulation.170.html

[12] Bogolyubov VM, Ponomarenko GN. General physiotherapy. 3rd ed. Moscow, SPb: SLP; 1998. 480 p.

\section{НОВЫЙ АЛГОРИТМ АНАЛИЗА ВИДЕОИЗОБРАЖЕНИЙ ОСЦИЛЛЯЦИЙ КЛЕТОК В МИКРОЧИПАХ}

Проблематика. Одним из быстро развивающихся направлений в науке является тканевая инженерия с использованием технологии “лаборатория на микрочипе”. Для оценки механических сокращений клеток используются оптическая микроскопия и анализ видеоданных. Однако известные методы регистрируют только фракт сокращения клеток и существенно искажают фрорму и амплитуду полезного сигнала. Поэтому задачи корректного количественного анализа таких видеоизображений являются актуальными.

Цель. Целью работы является разработка алгоритма анализа видеоданных механических сокращений кардиомиоцитов на микрочипе для определения их функциональных и структурных свойств на тканевом уровне. 
Методика реализации. Разработанный алгоритм анализа видеоизображений реализован программным кодом Маtlab 2016. Для апробации предложенного метода были проанализированы данные о сокращения клеток кардиомиоцитов, выращенных в микрочипе. Исследовались три группы клеток: выращенные без стимуляции, а также клетки, которые стимулировались электрическими полями 5 и 25 В/см. Форма стимулирующих импульсов - прямоугольная, частота - 1 Гц.

Результаты. Предложенный алгоритм анализа видеоданных, позволяет оценить скорость сокращения клеток в микрометрах за секунду. Кроме того, он позволяет разложить механические колебания клеток на компоненты. Алгоритм использовался для оценки изменения скорости сокращения кардиомиоцитов в зависимости от интенсивности напряжения и частоты возбуждения.

Выводы. Предложенный метод анализа видеоданных сокращений клеток кардиомиоцитов на микрочипе не требует каких-либо вспомогательных биомаркеров или сред. Анализ видеоизображений позволяет оценить амплитуду и скорость колебаний, фрорму сигнала, пространственно-неоднородное распределение механической активности клеток. Показано, что импульсное электрическое поле в диапазоне 5-25 В/см на частоте 1 Гц при культивировании клеток оказывает отрицательное влияние на сократительную способность кардиомиоцитов.

Ключевые слова: кардиомиоциты; клетки; органы на микрочипе; колебания; алгоритм; видеоданные; оптическая микроскопия; тканевая инженерия.

М.О. Ніколов, Р. Візоне, І.Г. Нестерук, М. Распоні, А. Редаеллі

\section{НОВИЙ АЛГОРИТМ АНАЛІЗУ ВІДЕОЗОБРАЖЕНЬ ОСЦИЛЯЦІЙ КЛІТИН У МІКРОЧИПАХ}

Проблематика. Одним із напрямів у науці, що швидко розвивається, є тканинна інженерія з використанням технології “лабораторія на мікрочипі”. Для оцінки механічних скорочень клітин використовуються оптична мікроскопія й аналіз відеоданих. Однак відомі методи реєструють тільки факт скорочення клітин і суттєво спотворюють форму й амплітуду корисного сигналу. Тому актуальним залишається кількісний аналіз таких відеозображень.

Мета. Метою роботи є розробка алгоритму аналізу відеоданих механічних скорочень кардіоміоцитів на мікрочипі для визначення їх функціональних і структурних властивостей на тканинному рівні.

Методика реалізації. Розроблений алгоритм аналізу відеозображень реалізовано програмним кодом Маtlab 2016. Для апробації запропонованого методу були проаналізовані дані про скорочення кардіоміоцитів, вирощених у мікрочипі. Досліджувалися три групи клітин: вирощені без стимуляції, а також клітини, які стимулювалися електричними полями 5 і 25 В/см. Форма стимулюючих імпульсів - прямокутна, частота 1 Гц.

Результати. Запропонований алгоритм аналізу відеоданих дає змогу оцінити швидкість скорочення клітин у мікрометрах за секунду. Крім того, він дає можливість розкласти механічні коливання клітин на компоненти. Алгоритм використовувався для оцінки зміни швидкості скорочення кардіоміоцитів залежно від інтенсивності напруги і частоти збудження.

Висновки. Розроблений метод аналізу відеоданих оптичної мікроскопії скорочень кардіоміоцитів на мікрочіпі не вимагає допоміжних біомаркерів або середовищ. Аналіз відеозображень дає змогу оцінити амплітуду і швидкість коливань, форму сигналу, просторовий розподіл механічної активності клітин. Показано, що імпульсне електричне поле в діапазоні 5-25 В/см на частоті 1 Гц при культивуванні клітин чинить негативний вплив на здатність кардіоміоцитів скорочуватись.

Ключові слова: кардіоміоцити; клітини; органи на мікрочипі; коливання; алгоритм; відеодані; оптична мікроскопія; тканинна інженерія. 